\title{
On the potential for regolith control of fluvial terrace formation in semi-arid escarpments
}

\author{
K. P. Norton ${ }^{1}$, F. Schlunegger ${ }^{2}$, and C. Litty ${ }^{2}$ \\ ${ }^{1}$ School of Geography, Environment and Earth Sciences, Victoria University of Wellington, Wellington, New \\ Zealand \\ ${ }^{2}$ Institute of Geological Sciences, University of Bern, Bern, Switzerland \\ Correspondence to: K. P. Norton (kevin.norton@vuw.ac.nz)
}

Received: 16 July 2015 - Published in Earth Surf. Dynam. Discuss.: 20 August 2015

Revised: 10 January 2016 - Accepted: 14 January 2016 - Published: 2 February 2016

\begin{abstract}
Cut-fill terraces occur throughout the western Andes, where they have been associated with pluvial episodes on the Altiplano. The mechanism relating increased rainfall to sedimentation is, however, not well understood. Here, we apply a hillslope sediment model and reported cosmogenic nuclide concentrations in terraces to examine terrace formation in semi-arid escarpment environments. We focus on the Pisco river system in western Peru in order to determine probable hillslope processes and sediment transport conditions during phases of terrace formation. Specifically, we model steady-state and transient hillslope responses to increased precipitation rates. The measured terrace distribution and sediment agree with the transient predictions, suggesting strong climatic control on the cut-fill sequences in western Peru primarily through large variations in sediment load. Our model suggests that the ultimate control for these terraces is the availability of sediment on the hillslopes, with hillslope stripping supplying large sediment loads early in wet periods. At the Pisco river, this is manifest as an approximately 4-fold increase in erosion rates during pluvial periods. We suggest that this mechanism may also control terrace occurrence other semi-arid escarpment settings.
\end{abstract}

\section{Introduction}

High-elevation plateaus are commonly associated with either passive margins (e.g. Africa, Sri Lanka, Australia) or large convergent mountain systems (e.g. Himalaya, Andes). In either case, erosion on the plateau edge leads to the formation of rapidly eroding escarpments adjacent to the more slowly eroding plateaus (Kober et al., 2006; Matmon et al., 2002; Seidl et al., 1996; van der Beek et al., 2002; Vanacker et al., 2007; von Blanckenburg et al., 2004; Weissel and Seidl, 1997). In this paper, we suggest that weathering is a dominant control on river form in escarpment settings as it is responsible for the production of sediment through the formation of regolith. The antiquity of most of these plateaus suggests that they erode through parallel retreat (Schlunegger et al., 2006) with somewhat constant topographic profiles. These large topographic gradients often result in orographic precipitation on the escarpment (see, e.g., Bookhagen and Strecker, 2008). Since chemical weathering is at least par- tially dependent on water supply (see, e.g., White and Blum, 1995a), regolith formation is also likely to be enhanced on the plateau, especially during wet phases.

Quaternary climate change has led to fluctuations in the available precipitation on both the plateaus and adjacent valleys. The fluvial cut and fill terrace systems, which are common in these settings, are typically attributed to this climate variability (Bookhagen et al., 2006; Steffen et al., 2009). Using a climate-dependent regolith production algorithm (Norton et al., 2014) coupled with simple sediment transport laws (see, e.g., Tucker and Slingerland, 1997), we investigate the effects of climate change in the form of precipitation variation on the hillslope system and propose that hillslope regolith production and stripping may control cut and fill sequences during the late Quaternary. 


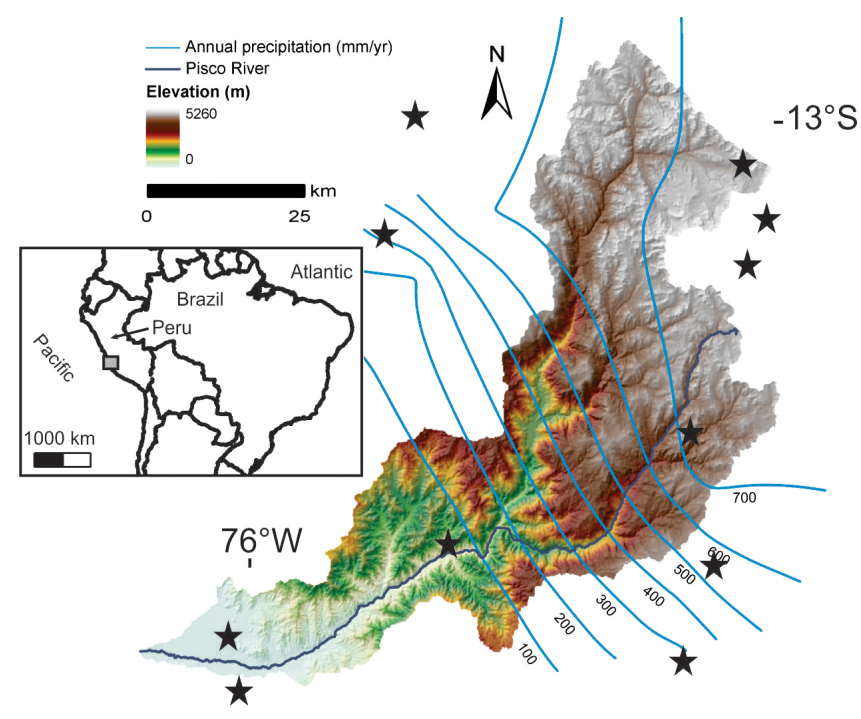

Figure 1. Setting and geomorphology of the Pisco river. Precipitation stations used to interpolate the annual rainfall are starred (Agteca, 2010).

\section{Setting}

We focus on the Pisco river drainage basin, situated on the western Andean margin at ca. $17^{\circ} \mathrm{S}$ in central Peru. This river flows from its headwaters at $\sim 4000 \mathrm{~m}$ a.s.l. across the Altiplano Plateau before plunging into a deeply incised canyon. This region marks a broad knickzone, which connects the mostly non-incised Miocene Altiplano Plateau to the flat, low-lying coastal plains (Fig. 1). The high-elevation plateau is characterized by high precipitation rates and low erosion rates, while the knickzone exhibits lower precipitation rates but much faster erosion (Fig. 2). The knickzone is interpreted to maintain its slope while eroding headward due to low erosion rates at the plateau margin (Abbühl et al., 2011). Above the knickzones, the streams are still graded to the Miocene base level. This high-elevation plateau could be the result of dynamic reorganization of river channels (Willett et al., 2014) and/or the uplift of the western Andes (see, e.g., Schlunegger et al., 2006; Schildgen et al., 2007). Along the knickzone, the Pisco river is currently under sediment capacity as evidenced by the narrow modern channel where the stream cuts into valley fill and bedrock. The upper river reaches are primarily bedrock channels, while lower reaches are alluvial. Downstream of the knickzone, the floodplain widens and the river becomes braided, attesting to an excess of sediment.

A series of cut-fill terraces and debris flow deposits fill the widening channel to within $\sim 40 \mathrm{~km}$ from the coast (see, e.g., Steffen et al., 2009; Bekaddour et al., 2014). These valley fills consist of both fluvial conglomerates and hillslopederived debris flow breccias, which could indicate phases of landsliding (see, e.g., McPhillips et al., 2014). We pro-

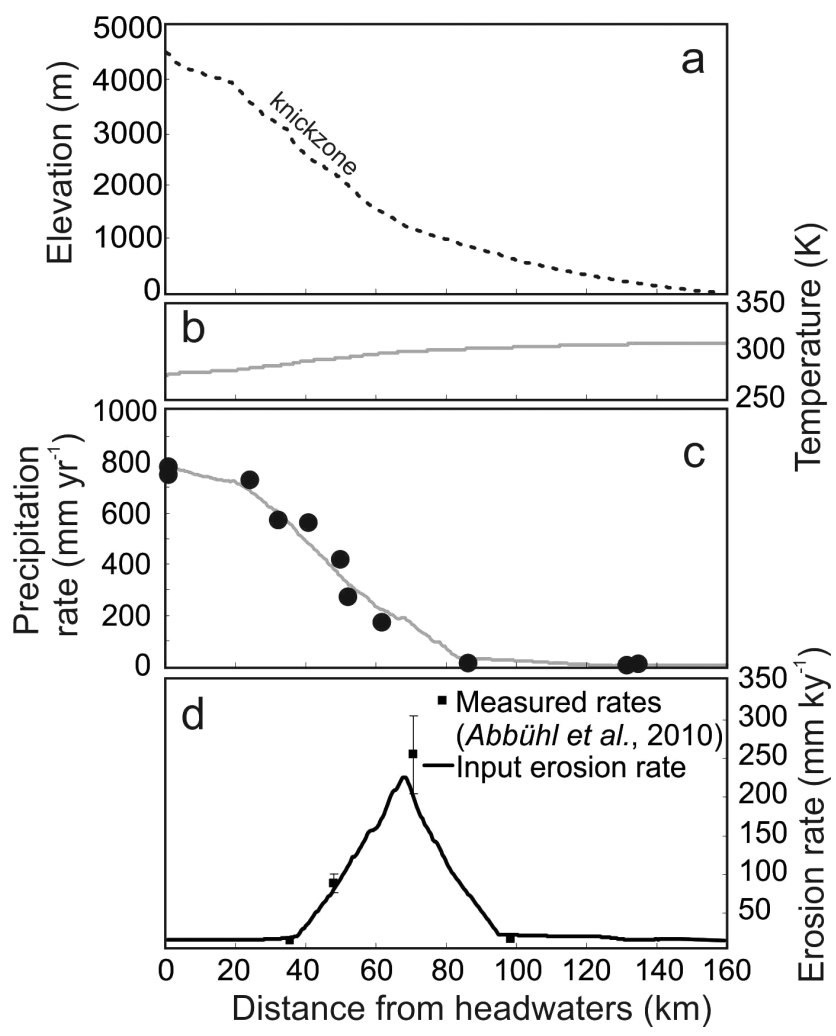

Figure 2. Geomorphic and climatic input parameters along the Pisco river including (a) river longitudinal profile, (b) temperature, (c) annual precipitation, and (d) erosion rate. Input rainfall stations (Agteca, 2010) projecting along strike onto the Pisco river profile are shown by filled circles; input erosion rates with errors (Abbühl et al., 2011) are shown by filled squares. Downstream erosion rates were estimated by spatially interpolating the erosion rate data of Abbühl et al. (2011) and extracting the long profile.

ceeded according to Litty et al. (2015) and measured the exposed thickness and extent of $>100$ terraces in the Pisco valley (Fig. 3). These were classified as fluvial (composed of moderately well-sorted, well-rounded clast-supported cobbles) or colluvial (composed of poorly sorted, angular to subrounded, matrix-supported clasts; Fig. 4). The terraces were correlated based on elevation and composition.

Steffen et al. (2009) dated the late Quaternary terraces, which are abundant in the lower reaches downstream of the knickzone from $\sim 40$ to $120 \mathrm{~km}$ downstream. The ages of the terrace accumulation correspond with well-known wet periods in the western Andes (e.g. Minchin, 47.8-36 ka and Tauca, 26-14.9 ka; Baker et al., 2001a, b; Fritz et al., 2004; Placzek et al., 2006). As documented by Steffen et al. (2009), regolith is shed over ca. 10-15 kyr timescales from the hillslopes as debris flows during these pluvial periods. These authors suggested that increased rainfall resulted in increased erosion and thereby increased sediment supply to the river, causing a phase of deposition in the valley, starting generally with debris flows from the hillslopes. They argued that 


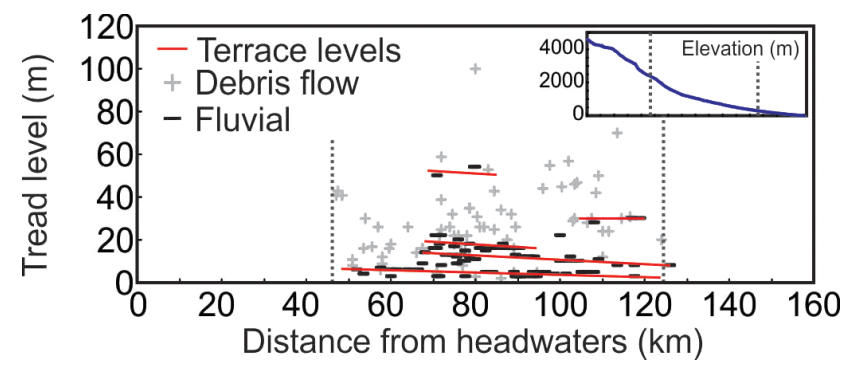

Figure 3. Locations of terraces along the Pisco river. The majority of terraces are concentrated in the zone from $\sim 50$ to $120 \mathrm{~km}$ downstream. Inset shows the location of the terraces (dashed lines) along the river profile.

as hillslopes became depleted of sediment, the river begins to incise again while discharge remains high. While this scenario is logical, the ability of sediment delivery from hillslopes to control fluvial transport has not been tested. In this contribution, we present a model linking the production of sediment through weathering with a sediment transport model to explore the conditions leading to the formation of the Pisco river terraces.

\section{Hillslope regolith}

The mechanisms and rates of weathered regolith production are commonly expressed in the context of erosion rates such that slower erosion rates are associated with thicker soil cover (see, e.g., Heimsath et al., 1997). The western Andean margin of Peru provides a setting in which weathered regolith is thick on the slowly eroding plateau but nearly absent at low elevations despite even lower erosion rates. This seeming contradiction is best explained by gradients in the governing climatic variables. White and Blum (1995b) showed that solute fluxes from a global compilation of granitic watersheds approach 0 as precipitation approaches 0 . In order to best model this gradient in soil thickness, we apply the climate-dependent regolith production model of Norton et al. (2014), which was based on the temperature- and precipitation-dependent weathering data of White and Blum (1995b). The model predicts time-transgressive or steadystate soil production rates and soil thicknesses for a given mean annual temperature, mean annual precipitation, and mean erosion rate. Temperature $(T)$, precipitation $(P)$, and silicate mineral activation energy $\left(E_{\mathrm{a}}\right)$ set the maximum soil production rate $\left(\mathrm{SPR}_{\max }\right)$ :

$\mathrm{SPR}_{\max }=\mathrm{a}_{0} P e^{\frac{-E_{\mathrm{a}}}{R}\left(\frac{1}{T}-\frac{1}{T_{0}}\right)}$,

where $R$ is the gas constant, $T_{0}$ is $5^{\circ} \mathrm{C}$, and $a_{0}=0.42$ is a precipitation scaling factor tuned to the Pisco soil data set (Norton et al., 2014). The instantaneous soil production rate (SPR) and change in soil thickness are calculated as a func-
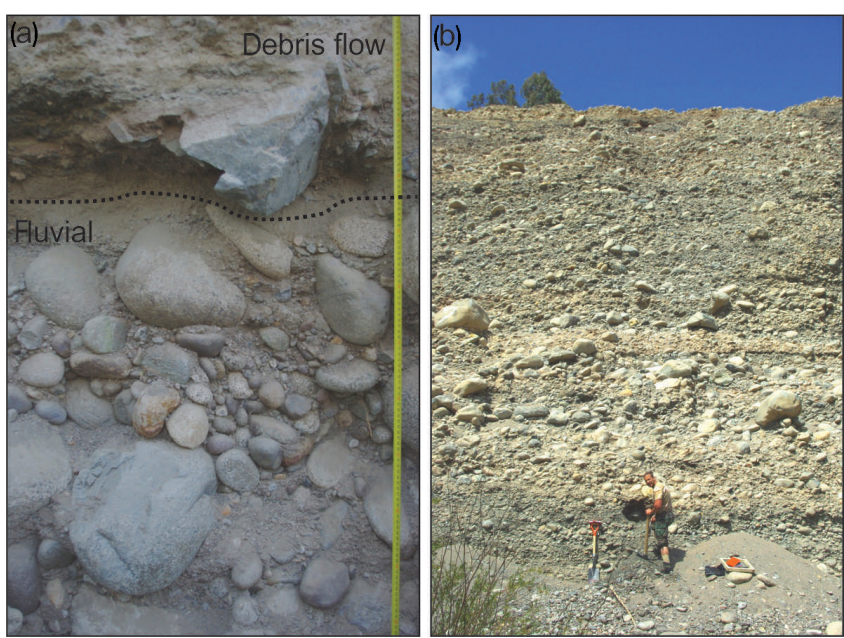

Figure 4. Rapid soil stripping in the Pisco valley is evidenced by abundant debris flow deposits (a, top) mixed with coarse, poorly sorted fluvial deposits ((a), bottom, and (b); note the person in (b) for scale).

tion of soil depth $(H)$,

$\mathrm{SPR}=\mathrm{SPR}_{\max } e^{-\alpha H}$,

and local mass balance,

$\frac{\mathrm{d} H}{\mathrm{~d} t}=a_{0} P e^{\frac{-E_{\mathrm{a}}}{R}\left(\frac{1}{T}-\frac{1}{T_{0}}\right)} e^{-\alpha H}-D$,

where $\alpha=0.03 \mathrm{~cm}^{-1}$ is the soil depth scalar (see, e.g., Heimsath et al., 1997) determined as the best fit to the Pisco data set (Norton et al., 2014) and $D$ is the denudation rate. Globally, $\alpha$ has been measured between 0.017 and $0.042 \mathrm{~cm}^{-1}$ (Heimsath et al., 2001, 2005). The highest values result in slightly thinner soils that are equivalent within error to the modelled soil thicknesses using $\alpha=0.03 \mathrm{~cm}^{-1}$ (see Norton et al., 2014). Lower values of $\alpha$ result in significantly thicker soils, which would enhance river sediment loads during rapid soil stripping. Rapid soil production rates and thick soils are predicted for high temperatures and precipitation amounts. Erosion rates are the ultimate control on the output soil thickness and system response time.

\subsection{Regolith thickness in the Pisco river drainage basin}

We test the sensitivity of the Norton et al. (2014) model to the different input variables by allowing one variable to change while holding the other two at the plateau value (Fig. 5). In the model, temperature and precipitation influence the maximum soil production rate (Eq. 1), while erosion determines the overall mass balance (Eq. 3). Precipitation and erosion have the largest individual control on the calculated steady-state regolith thickness. The temperature effect is much smaller. As such, variations in temperature (both intra-annual and interannual) are negligible com- 


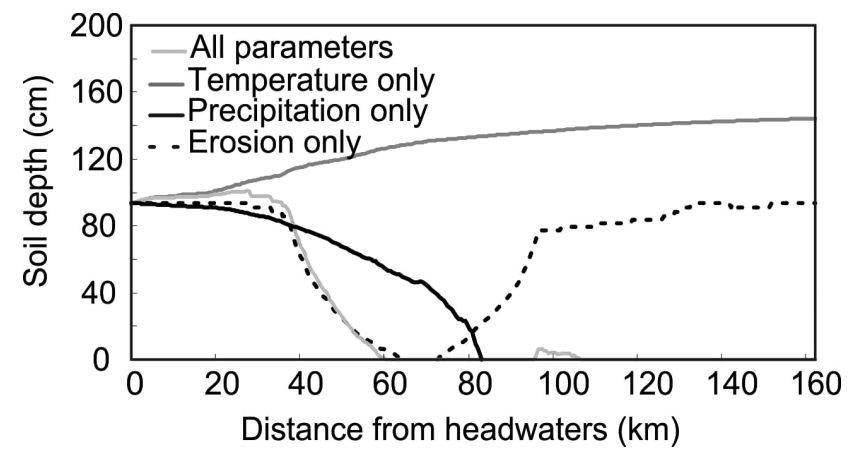

Figure 5. Sensitivity of the Norton et al. (2014) soil production model to each input parameter for the longitudinal profile of the Pisco river. The light grey line shows predicted soil thickness in the downstream direction using all parameters. We then held all other variables constant and allowed the temperature (darker grey line), precipitation (black line), and erosion (dashed line) to change downstream.

pared to other parameters. If regolith thicknesses were dependent on temperature alone, the model predicts a more or less uniform blanket over the entire catchment, increasing slightly towards the coast as temperatures get warmer. In contrast, regolith depth would decrease rapidly towards the coast in a solely precipitation-dependent state, approaching 0 at $\sim 100 \mathrm{~km}$ from the headwaters. Finally, if erosion were the sole process controlling and limiting regolith thicknesses, the value of this variable would be expected to decrease in the rapidly eroding knickzone but to thicken again farther downstream. We note that in all cases, a positive dependence of the maximum soil production rate $\mathrm{SPR}_{\max }$ on erosion, as proposed by Heimsath et al. (2012), would result in thicker soil cover over a wider range of erosion rates but should not change the overall distribution of soils from the model. The modelled regolith depths generally match the sparse measured depths from ridgetops in the Pisco valley (see, e.g., Norton et al., 2014). Ridgetops were sampled for soil depth as the hillslopes throughout the escarpment tend to be stripped bare of weathered material in the modern climate. Additionally, the rugged terrain, poor access, and lack of drillings precluded the collection of further data.

\subsection{Hillslope sediment delivery mechanisms}

Sediment supply to the river was calculated by combining the climate-dependent soil production model (Norton et al., 2014) with cosmogenic nuclide-derived denudation rates (Abbühl et al., 2010, 2011; Bekaddour et al., 2014). To determine modern sediment supply, we allow the Pisco river to erode at its long-term rate as determined by cosmogenic nuclides, assuming no hillslope storage (an assumption vital to the cosmogenic nuclide methods as well; see, e.g., von Blanckenburg, 2006). The modern discharge is taken as the basin integrated precipitation rate (Agteca, 2010), which de- creases downriver yielding an average discharge of $20 \mathrm{~m}^{3} \mathrm{~s}^{-1}$ along the coastal section. As such, we ignore the effects of evapotranspiration and infiltration but still capture a more realistic discharge for the Pisco, which is ca. $23 \mathrm{~m}^{3} \mathrm{~s}^{-1}$ as measuring at the gauging station of Letrayoc (Bekaddour et al., 2014).

We model two potential responses to increased rainfall during pluvial periods: a steady-state increase in denudation rate and transient stripping of hillslope sediment (Fig. 6). We consider steady state to be the case where the soil production response time is significantly shorter than the timescale over which long-term climate changes (i.e. soil transitions smoothly between steady-state thicknesses). Based on cosmogenic nuclide concentrations from the Piura River in northwestern Peru, Abbühl et al. (2010) showed that, in steady state, denudation rates increase exponentially with increasing precipitation rates below the plateau edge but are independent of precipitation on the plateau. Our first model assumes this relationship to hold in time as well as space. We therefore hold the denudation rate constant on the plateau throughout time but vary the denudation rate below the plateau edge as $D_{2}=D_{1} \times \exp ^{c P}$ (where $D_{2}$ and $D_{1}$ are the predicted and initial denudation rate $\left(\mathrm{mm} \mathrm{yr}^{-1}\right)$, respectively, $P$ is the mean annual precipitation $(\mathrm{mm})$, and $c=0.0041$ is empirically derived for the western Andes; Abbühl et al., 2010) up to the limit of soil thickness (i.e. the maximum allowable erosion rate is the soil production rate).

The transient model is based on the widespread presence of debris flow deposits in the terraces and the rapid accumulation rates suggested by OSL (optically stimulated luminescence) dating (Steffen et al., 2009). These observations suggest that sediment is rapidly eroded from the hillslopes during pluvial periods, resulting in a sediment pulse into the basin. To model this transient sediment delivery, we assume complete hillslope stripping downstream of the knickzone (where slopes are steep) upon initiation of the pluvial period followed by negligible erosion after the hillslopes become bare of sediment (se, e.g., Fig. 6). We compare the longitudinal sediment transport capacity / sediment load ratios to the existing terrace distribution in the Pisco valley.

\section{Fluvial transport}

The eroded material delivered to the channels will either be deposited or transported, depending on the transport capacity of the stream. Channel flow and potential incision in these streams are typically expressed in terms of shear stress and sediment transport equations, and flow is driven by temporally variable (but spatially homogeneous) precipitation.

We begin by coupling the weathering-dependent model with an algorithm that describes sediment transport in channels and apply it to the long profile of the Pisco river. Sediment transport capacity $T_{\mathrm{c}}$ is calculated using the Bagnold 


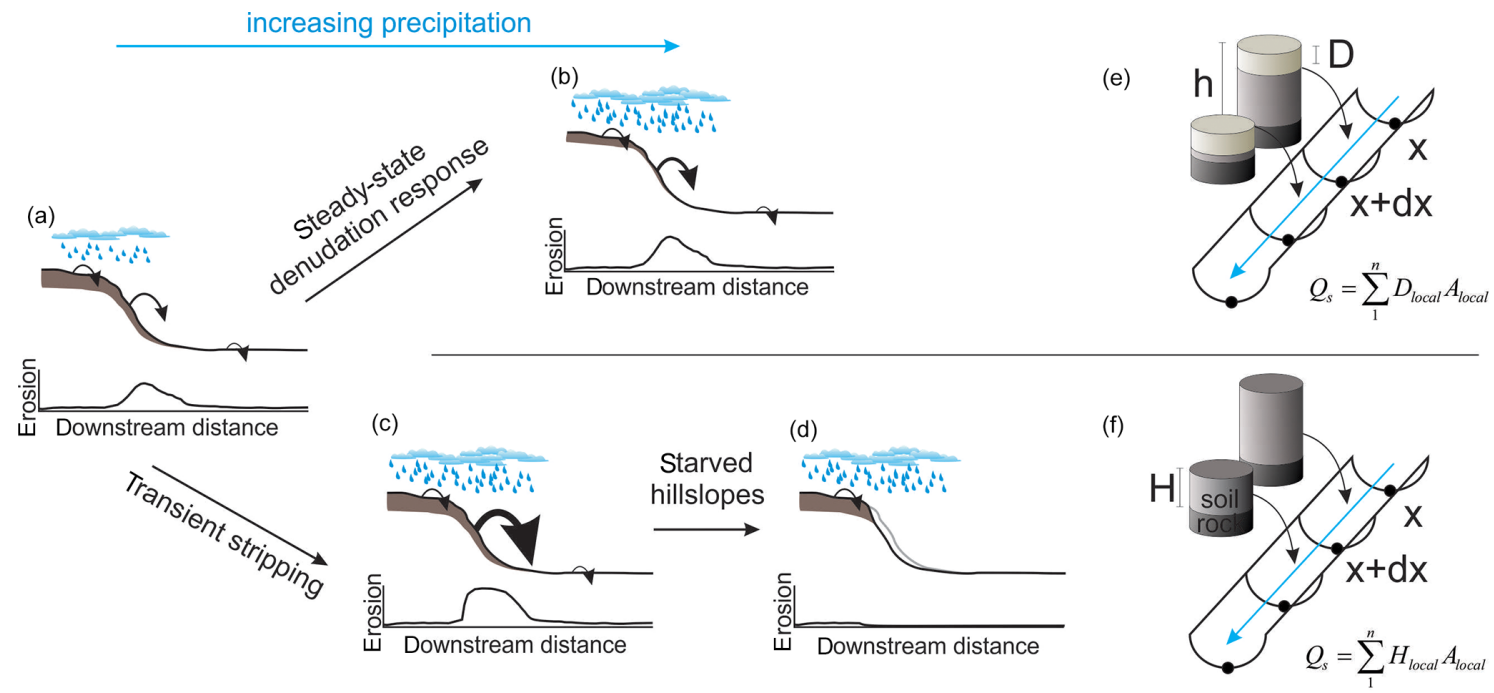

Figure 6. Conceptual model of two modes of hillslope response to increased precipitation in semi-arid environments. Arrow size represents the relative contribution of eroded hillslope sediment to the river. In the steady-state case $(\mathbf{a}, \mathbf{b})$, increased precipitation results in increased hillslope erosion rates on steep hillslopes which are balanced by increased soil production (see, e.g., Norton et al., 2014). In the transient case (a, c, d), increased precipitation results in rapid stripping of hillslope sediment as debris flows and shallow landslides (c) occur, followed by negligible erosion on steep hillslopes once the soil mantle is eroded (d). The model setup for each of these scenarios is shown in (e) (steady state) and (f) (transient stripping). The steady-state model (e) calculates the sediment load $Q_{\text {s }}$ as the sum of sediment delivered by erosion (erosion rate $\times$ time step $\times$ local area) at each node. To model transient hillslope stripping, we remove the entire soil thickness (soil thickness $\times$ time step $\times$ local area) at each node. These model setups provide endmember scenarios for hillslope response to changing climate.

equation (see, e.g., Tucker and Slingerland, 1994, 1997):

$T_{\mathrm{c}}=\frac{B W}{\left(\rho_{\mathrm{s}}-\rho_{\mathrm{w}}\right) \rho^{1 / 2} g}\left(\tau-\tau_{\mathrm{c}}\right)\left(\tau^{1 / 2}-\tau_{\mathrm{c}}^{1 / 2}\right)$,

where $B$ is a constant equal to 10 (see, e.g., Hancock and Anderson, 2002), $W$ is channel width, $\rho_{\mathrm{s}}$ and $\rho_{\mathrm{w}}$ are the densities of sediment and water, respectively, $g$ is gravity, $\tau$ is the applied bed shear stress, and $\tau_{\mathrm{c}}$ is the critical shear stress for the entrainment of the $D_{50}$, which is the 50th percentile grain size. Note that here we calculate sediment transport capacity, and the actual sediment discharge is dependent on the sediment yield of the basin. We scale channel width to catchment area $A$ using the empirical geometry relationship, $W=a A^{b}$ (see, e.g., Yalin, 1992), fitted to the Pisco river, where $a$ is 0.015 and $b$ is 0.95 (Fig. 7).

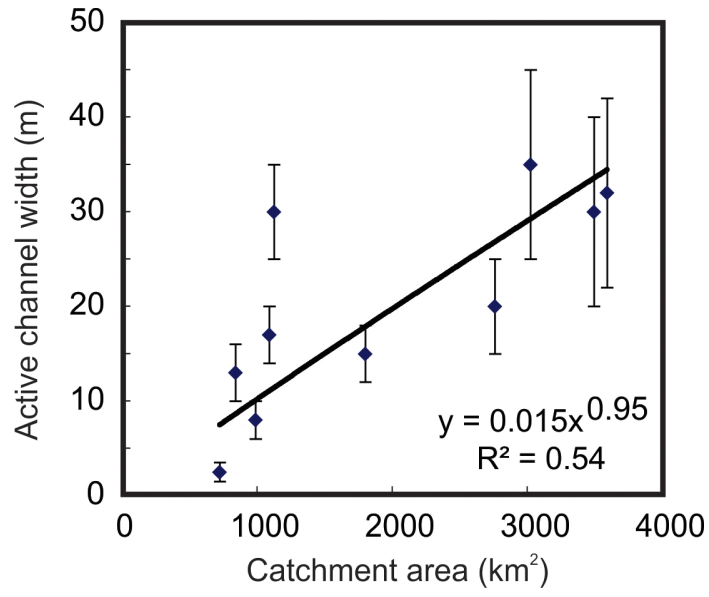

Figure 7. Active-channel-width-to-area scaling for the Pisco river.

Shear stress is calculated as

$$
\tau=\rho_{\mathrm{w}} g\left(\frac{Q_{\mathrm{w}}}{W}\right)^{3 / 5} n^{3 / 5} S^{7 / 10}
$$

(after Hancock and Anderson, 2002), where $Q_{\mathrm{w}}$ is the water discharge, $n$ is Manning's $n$, and $S$ is the channel gradient. Critical shear stress is calculated as

$\tau_{\mathrm{c}}=0.047\left(\rho_{\mathrm{s}}-\rho_{\mathrm{w}}\right) g D_{50}$ 
(see, e.g., Leopold et al., 1964), where $D_{50}$ is the 50th percentile grain size, here taken to be the mean grain size measured in the Pisco valley terraces, i.e. $0.02 \mathrm{~m}$ (Litty et al., 2015). We applied a Shield's parameter of 0.047, which is consistent with the suggestions proposed by MeyerMüller (1948) and Heller and Paola (1992) for these streams.

The cumulative sediment supply is calculated as the sum of the upstream hillslope erosional fluxes contributing to point $n$ along the channel:

$Q_{\mathrm{s}}=\sum_{i=1}^{n} D_{i} A_{i}$

Water discharge is likewise calculated as the sum of the upstream area and precipitation amount:

$Q_{\mathrm{w}}=\sum_{i=1}^{n} c P_{i} A_{i}$

where $A_{i}$ is the lateral contributing hillslope area $\left(\mathrm{m}^{2}\right)$ to point $i$ in the channel, $P_{i}$ is precipitation $\left(\mathrm{mm} \mathrm{a}^{-1}\right)$ and $D_{i}$ is erosion $\left(\mathrm{mm} \mathrm{a}^{-1}\right)$ from this area, and $c$ is a runoff coefficient. The runoff coefficient accounts for losses due to evapotranspiration and infiltration. Because of a lack of data, we assume in this study that $c=1$; however, it is likely that the coefficient is smaller as evapotranspiration (see, e.g., Bloschl et al., 2013) and infiltration in the lower reaches of the Pisco river lead to lower discharge downstream. In this case, $T_{\mathrm{c}}$ will decrease more rapidly downstream.

The fluvial transport model, while simple in its approach, provides a first-order estimate of river response in this system. The 1-D model is not capable of representing changes in fluvial transport style or changing hydraulic parameters. This is especially noticeable in our treatment of hydraulic geometry and shear stress which are calculated using empirical relationships (see, e.g., Hancock and Anderson, 2002; Shields, 1936). We adopted this approach as a more formal treatment of roughness and skin friction (see, e.g., Ferguson, 2007) would require knowledge of flow velocity or depth which are lacking for the Pisco river. Despite these limitations, the shear stress approach has been shown to adequately model strath terrace formation, which involves both erosion and deposition in the fluvial system (Hancock and Anderson, 2002).

\subsection{Coupled hillslope-river model}

We apply the 1-D coupled sediment-transport-weatheringdependent soil model to the Pisco river using $1 \mathrm{~km}$ node spacing (Fig. 6e, f). All dependent variables can be freely changed at each node (e.g. spatially variable denudation rates, precipitation rate, and temperature). We take precipitation rates from the Global Historical Climatology Network compilation of Agteca (2010), which are based on 493 individual rain gauges measured over 10 to 85 years (mean 20 years) within Peru. For the Pisco river model inputs (Fig. 2), we use the long-profile trend of precipitation based on an interpolation of the 17 rain gauges that are within $25 \mathrm{~km}$ of the catchment. The largest interannual variability occurs on the plateau where annual rainfall is the highest. Relative rates are, however, highest near the coast where large single events can more than double the annual averages (Fig. 8b). Garraud et al. (2003) used an atmospheric transport model which excluded ocean dynamics to estimate glacial-interglacial climate on the Altiplano. Their $\sim 10-20 \%$ modelled glacialinterglacial precipitation variability through the late Quaternary matches the $\sim 16-18 \%$ interannual variability on the Altiplano from the Agteca (2010) data set. As such, we assume that the 20 -year data are at least broadly representative of long-term precipitation and use the relationship between absolute precipitation rate and relative variability (Fig. 8b) to test the sensitivity of the model and propagate errors. Both sediment transport capacity and sediment load are dependent on precipitation. Decreased precipitation on the plateau could lead to transport-limited streams through decreased sediment transport capacity (Fig. 9). Otherwise, within realistic limits, precipitation does not significantly change our results.

Temperature is determined for each node, assuming an atmospheric lapse rate of $6^{\circ} \mathrm{C} \mathrm{km}^{-1}$ and the mean annual temperature of $12.8^{\circ} \mathrm{C}$ of Cusco, Peru, at $3204 \mathrm{~m}$ elevation a.s.l. Temperatures during the Last Glacial Maximum are estimated to have been $5-9^{\circ} \mathrm{C}$ lower on the Altiplano (Baker et al., 2001). The sensitivity of the coupled model to temperature is tested within the glacial-interglacial variability. As temperature only affects the maximum soil production rate, it has no effect on the transport capacity or the sediment load on the plateau, where erosion rates are held constant (Fig. 9).

Denudation rates for the Pisco river have been measured by Abbühl et al. (2010) and complemented by Bekaddour et al. (2014). We use a tensioned spline (weight 0.1) to interpolate denudation rate values for each point along the river profile. Denudation rates reach a maximum of $\sim 250 \mathrm{~mm} \mathrm{a}^{-1}$ in the knickzone and are much lower on both the plateau and near the coast at $\sim 11 \mathrm{~mm} \mathrm{a}^{-1}$. We exclude one sample (Pis 11) from the data set of Abbühl et al. (2011) as it is most likely heavily influenced by the recycling of shielded sand from the $\sim 50 \mathrm{ka}$ conglomerate terraces and therefore does not represent the basin-wide denudation rate at this point. These long-profile values are used as inputs to calculate soil depths along the Pisco valley and to determine sediment delivery to the channel. Sediment load is controlled by erosion rate in the model. At very rapid erosion rates, the sediment loads may exceed transport capacity on the plateau (Fig. 9). In all other scenarios, erosion variation does not change our results. 


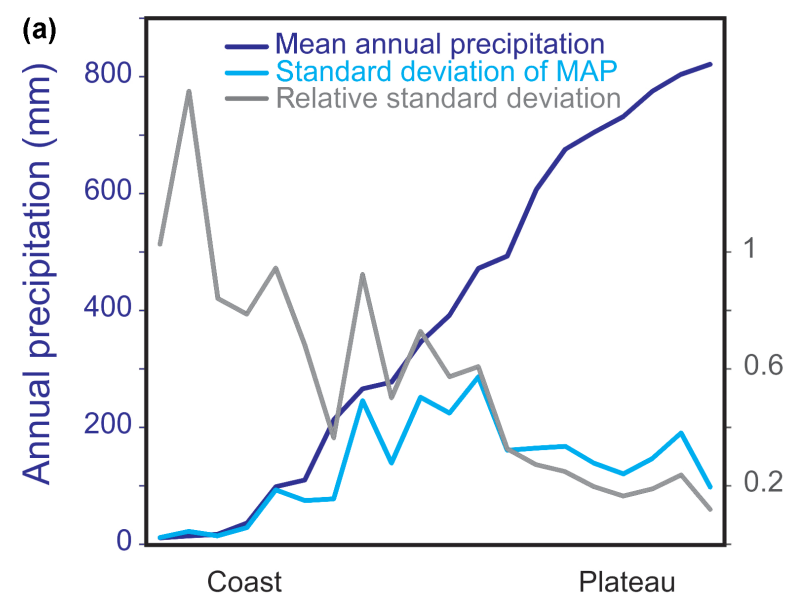

(b)

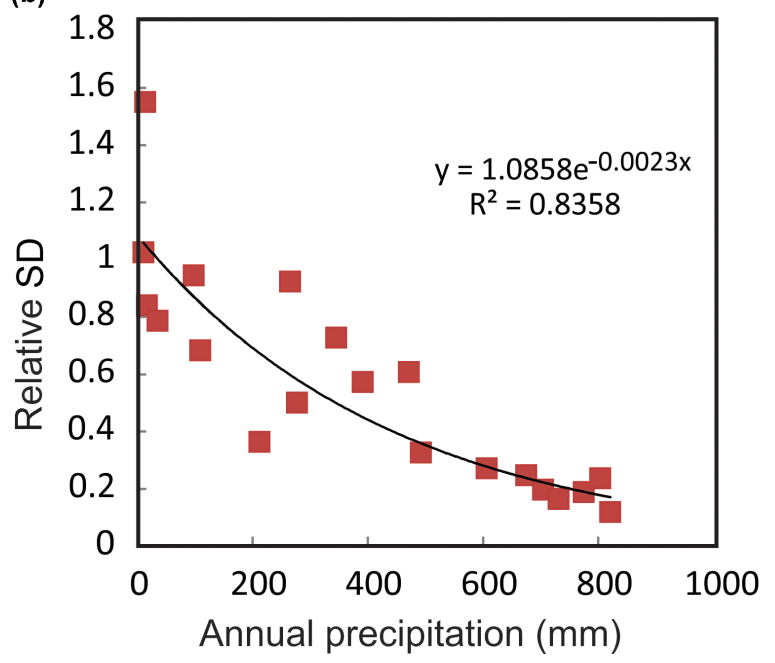

Figure 8. Variation in annual precipitation calculated from 20-year monthly averages (Agteca, 2010). The relative interannual variability is largest near the coast, where El Niño years bring increased precipitation (a). The relationship between relative variability and annual precipitation (b) was applied to the soil production and transport models and carried through as uncertainty (Figs. 9 and 10).

\subsection{Sediment load and transport}

Calculated modern sediment transport capacity and sediment flux (determined from ${ }^{10} \mathrm{Be}$-derived denudation rates, $\mathrm{Ab}$ bühl et al., 2010) show that the transition from supply limit to transport limit coincides with the upstream appearance of terraces (Fig. 10). Note that supply and transport limits refer in this case to excess transport capacity and sediment load, respectively. We also acknowledge that the terrace sediments represent primarily the bedload flux, while the cosmogenic nuclide-derived sediment flux is total load (i.e. dissolved load, suspended load, and bedload). This is because cosmogenic nuclides record total land surface lowering, whether through chemical or physical weathering, and terraces are by necessity built only of the physical load. As such, our estimated sediment loads are likely a maximum.
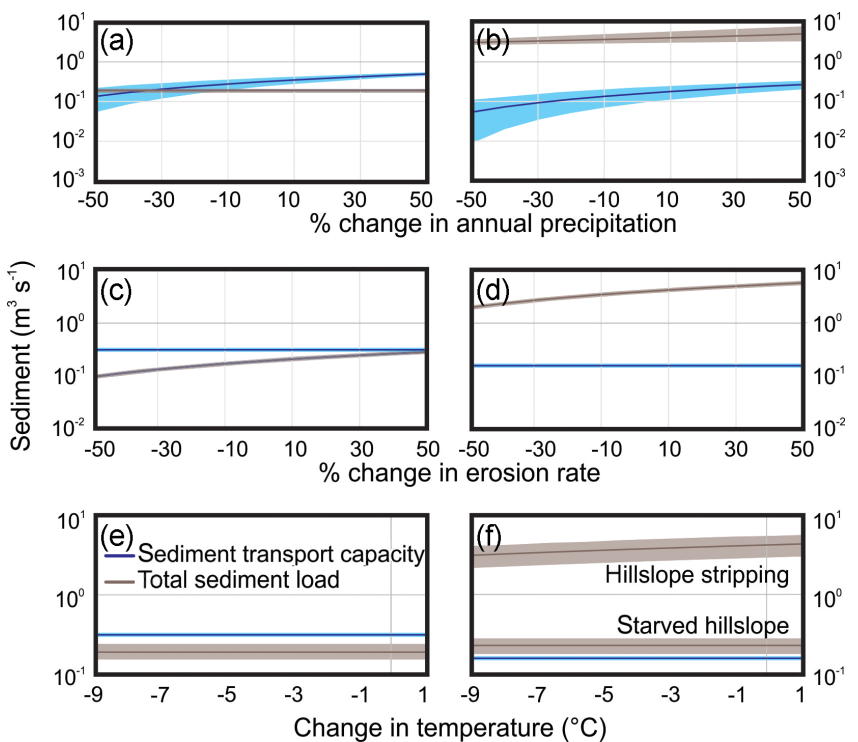

Figure 9. Response of sediment transport capacity (blue lines) and total sediment load (brown lines) to changes in annual precipitation $(\mathbf{a}, \mathbf{b})$, erosion rate $(\mathbf{c}, \mathbf{d})$, and temperature $(\mathbf{e}, \mathbf{f})$ for nodes on the plateau $30 \mathrm{~km}$ downstream (a, c, e) and beyond the knickzone $100 \mathrm{~km}$ downstream (b, d, f). Each variable was changed within the estimated range for glacial-interglacial fluctuations (Baker et al., 2001; Garaud et al., 2003). The uncertainty for precipitation response $(\mathbf{a}, \mathbf{b})$ is propagated from the modern variability (Agteca, 2010; Fig. 7). We assume an average $10 \%$ uncertainty in erosion rates $(\mathbf{c}, \mathbf{d})$ derived from cosmogenic nuclides and a $30 \%$ uncertainty in temperature $(\mathbf{e}, \mathbf{f})$ reflecting large uncertainties in the lapse rate. In all cases, the long-term variability does not likely change our model results. The exception to this is that sediment transport capacity on the plateau can drop below the sediment load at very low annual precipitation (a) or very fast erosion (c).

Even with this caveat, the stream is supply limited in the upper bedrock-floored sections and transport limited further down where cut-fill terraces are abundant, and the modern river flows over a wide floodplain made up of gravelly sediments. In the case that the Pisco river basin maintains steady state (e.g. the response time of the weathering system is faster than the rate of climate change), the main response to a doubling of modern precipitation rates (using Eq. 8 for water flux and Eq. 7 for the erosional flux) is for the stream to aggrade over a relatively short $\sim 20 \mathrm{~km}$ long section below the knickzone (Fig. 10b). During drier climates, the sediment transport capacity in this zone exceeds the loads as denudation rates are low. According to this simulation of wet and dry steady states, extensive cut-and-fill terraces should only be common in a narrow band near the knickzone. Farther downstream, sediment flux exceeds sediment transport capacity both during wet and dry phases and the stream primarily aggrades.

A transient stripping scenario is suggested by the results of Steffen et al (2009). According to Fig. 3 in their paper, the transition towards a more humid climate resulted 

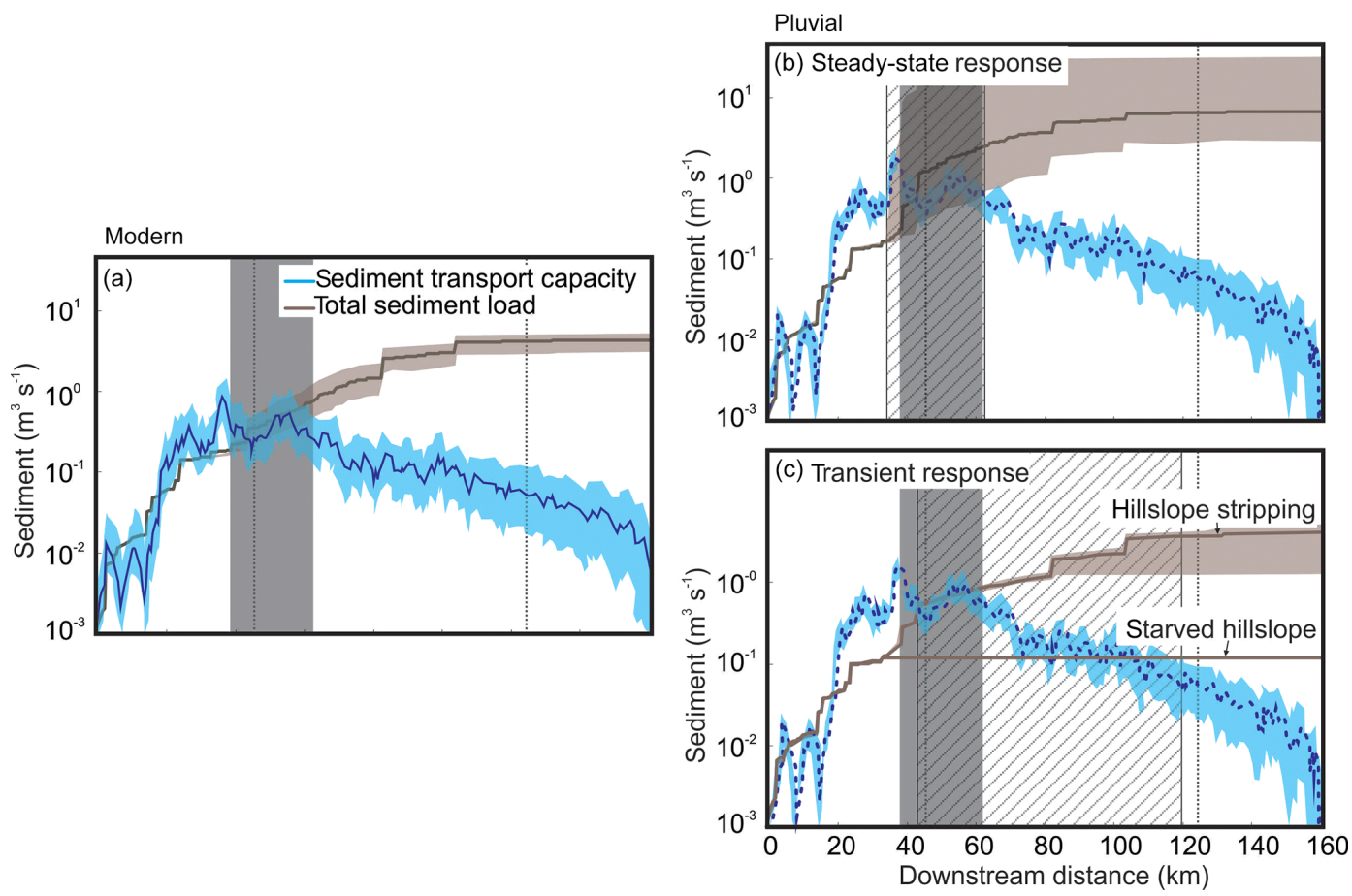

Figure 10. Model of hillslope erosion through (a) steady-state erosion and (b) transient hillslope stripping. In each graph, the solid grey area indicates the range of the modern bedrock-alluvial transition. The cross-hatched area indicates the endmember locations of the bedrockalluvial transitions for each scenario. The grey stippled lines indicate the location of the Pisco river terraces. In the steady-state case, the sediment load, $Q_{\mathrm{s}}$, is proportional to the aerially summed upstream denudation rate, $D$, even if there is a thick regolith mantle (h). The result is a minimal shift in the bedrock-alluvial transition (the point at which sediment load exceeds sediment transport capacity; Tucker and Slingerland, 1997) between wet and dry phases (b). In the transient case, the entire modelled soil mantle (after Norton et al., 2014) is stripped during a wet phase such that the sediment load, $Q_{\mathrm{s}}$, is proportional to the aerially summed upstream regolith mantle, $H$, followed by a lack of sediment during the starved phase. The modelled result is a significant downstream shift in the bedrock-alluvial transition (c), which roughly corresponds to the observed occurrence of terraces in the Pisco valley.

in an episodic phase of erosion, where regolith was rapidly stripped from hillslopes below the plateau over $\sim 10-15 \mathrm{kyr}$, supplying large volumes of sediment to the trunk stream. These phases of fluvial aggradation are followed by waves of incision travelling back up-valley. This suggests that an episodic phase of rapid hillslope stripping occurs, resulting in a large sediment pulse to the rivers, followed by a rapid drop-off of hillslope-derived sediment as the hillslope reservoirs are emptied. We model this transient response towards a more humid climate as a two-step process. Upon initiation of the wet period, all weathered regolith (calculated from the model) below the plateau is stripped from the hillslopes and supplied to the stream. In the second step, the bare hillslopes are unable to contribute new sediment to the stream. This is exacerbated by potentially faster erosion rates during the wet phases that inhibit the formation of a significant regolith cover. In this scenario, sediment supply to the stream during this step is controlled solely by inputs from the plateau, with little to no sediment being supplied from below the plateau. This pulsed transient case necessitates sufficient time having elapsed between wet periods for the weathered regolith to build up to the steady-state values (Bekaddour et al., 2014).
This is the case for the $\sim 10 \mathrm{kyr}$ climate intervals in western Peru. For the Pisco river knickzone, modern erosion rates range from $\sim 50$ to $250 \mathrm{~mm} \mathrm{a}^{-1}$ (Abbühl et al., 2011), with annual precipitation between $\sim 100$ and $400 \mathrm{~mm}$ (Agteca, 2010). This results in soil response times (90\% of the steadystate value) of 5.3-25 kyr (Norton et al., 2014). The result of this simulation is that sediment accumulates over the entire downstream reach of the stream as regolith is rapidly stripped from the hillslopes. Once this material is exhausted, however, the bedrock-alluvial transition moves approximately $100 \mathrm{~km}$ upstream, incising the valley fill (Fig. 10c). This scenario is more consistent with the observed occurrence of terraces in the Pisco river (Fig. 3). This scenario is also supported by ${ }^{10} \mathrm{Be}$-derived palaeo-denudation rates (Fig. 11; Bekaddour et al., 2014). The first sediments deposited during each wet phase are debris flow breccias with high ${ }^{10} \mathrm{Be}$ concentrations (lower palaeo-denudation rates), indicative of long residence time on the hillslopes. The subsequent fluvial gravels are derived from sediment with shorter residence times (higher palaeo-denudation rates). The continued contribution of fluvial sediment with high palaeo-denudation rates suggests that the reality most likely lies between the steady-state 


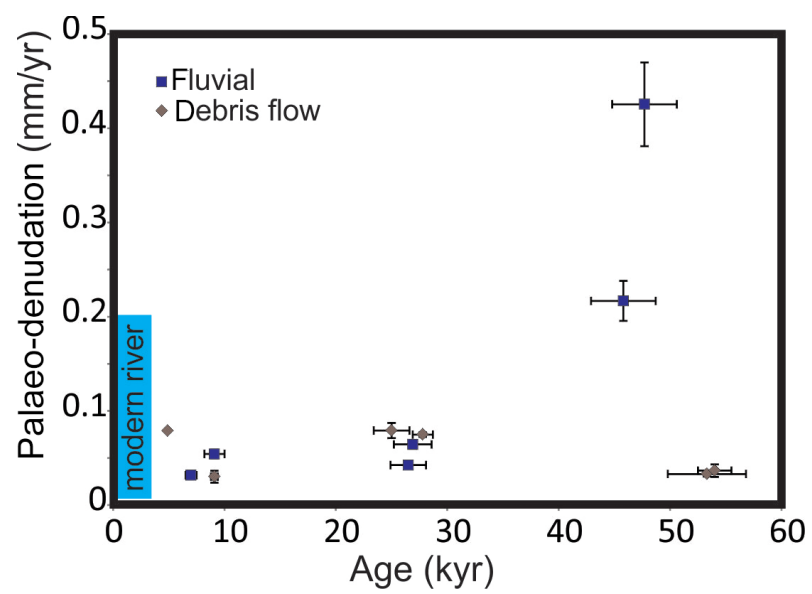

Figure 11. Accelerated erosion following initial deposition of debris flow material supports the idea of rapid stripping of a stable regolith mantle. The initial high concentrations (low palaeodenudation rates) for the debris flow deposits could represent long residence time on hillslopes, while the low concentrations (high palaeo-denudation rates) for the fluvial material could be the result of rapid removal of the regolith cover (data after Abbühl et al., 2011; Bekaddour et al., 2014).

and pulsed transient cases. However, these endmember scenarios can be informative for understanding terrace formation in escarpment environments.

\section{Discussion and conclusion}

Fluvial aggradation in the Pisco river has been associated with wet periods (Steffan et al., 2009). This has important consequences for regolith production on the western escarpment. On the plateau, where precipitation rates are $\sim 1000 \mathrm{~mm} \mathrm{a}^{-1}$ and denudation rates $\sim 10 \mathrm{~mm} \mathrm{a}^{-1}$, the response time of soils is $>100 \mathrm{kyr}$ (Norton et al., 2014). In the knickzone, precipitation is $\sim 100-400 \mathrm{~mm} \mathrm{a}^{-1}$ and denudation rates are $100-250 \mathrm{~mm} \mathrm{a}^{-1}$. This results in soil response times of $\sim<10 \mathrm{kyr}$. More importantly, the knickzone reach lies in a special climatic and denudational setting, in which small decreases in precipitation or increases in denudation can push the system into a state where regolith production rates are unable to keep up with denudation. Once conditions become amenable to regolith formation again, cover can reform on millennial timescales on the hillslopes due to the rapid response times (Norton et al., 2014).

When applied to the modern Pisco river the model suggests transient behaviour. In the long term, knickzone migration erodes into the plateau as the river adjusts to a lower base level. In addition to the direct control that base level has on the river, undercutting can dramatically change the rates and style of hillslope response (Roering et al., 2015; Bilderbach et al., 2015). In the Pisco valley case, little sediment is available in the knickzones and the response may resemble the
Waipaoa catchment in New Zealand, where base level lowering generated abundant deep-seated landslides (Bilderbach et al., 2015). Such a response is partially supported by the presence of large boulders in the channels and coarse angular clasts in the debris flow deposits. In the short term, hillslopes are quickly stripped of sediment, decoupling hillslope regolith from the incising channel. Key to both of these processes is that the timescale of hillslope stripping (as implied by the occurrence of debris flows) is less than the timescale of regolith production. For instance, an increase in precipitation rates can lead to a temporary increase in denudation rates (Tucker and Slingerland, 1997) until the hillslopes are stripped of sediment, exposing bedrock (Carson and Kirkby, 1972). The regolith is then regenerated during intermediate climates. An additional complication, recently suggested by Heimsath et al. (2012), is that the maximum regolith production rate may also be dependent on erosion rates such that faster erosion rates yield faster production rates. While we have not built this relationship into this study, we note that such a relationship would lead to enhanced regolith thickness in the knickzones and have no effect on the slowly eroding plateau or coastal plains.

The model clearly shows that regolith production on hillslopes has a large impact on sediment flux in the river. The sequences of cut-fill terraces observed in the Pisco river are more consistent with transient hillslope stripping during wet phases, followed by incision once the hillslopes are bare of regolith. This can have significant consequences for the evolution of bedrock streams in particular, where incision rates are at least partially dependent on sediment flux (Whipple and Tucker, 2002). It is interesting to note that much of the terraced zone does not adhere to the definition of a bedrock channel presented by Turowski et al. (2008) since much of the erosion acts on previous fill. In this case, the bedrockalluvial transition of Tucker and Slingerland (1996) is better defined as underload or overload, with the result being local erosion or deposition of the substrate, be it bedrock or sediment. Large changes in sediment delivery will also result in significant changes in hydraulic geometry, channel gradient, and erosion regime, both at a station and downstream. Deposition during high sediment load phases would flatten and widen the rivers, temporarily reducing driving stress. For the transient case presented here, this would enhance the modelled relationship leading to larger variation between erosional and depositional phases.

The occurrence of cut-fill terraces in the Pisco river is best explained by a pulsed transient response in which increased precipitation rates strip hillslopes of weathered material. The hillslopes remain bare until climate again becomes amenable to the preservation of weathered regolith. Such a scenario could be important in other escarpment settings.

Acknowledgements. The authors would like to thank M. Trauerstein and T. Bekaddour for assistance in the field. Two anonymous 
reviews and excellent editorial handling by Simon Mudd have improved the manuscript. This work was supported in part by a VUW Faculty of Science grant to K. P. Norton and Swiss National Science Foundation (SNF) grant 200020_155892 awarded to F. Schlunegger.

Edited by: S. Mudd

\section{References}

Abbühl, L. M., Norton, K. P., Schlunegger, F., Kracht, O., Aldahan, A., and Possnert, G.: El Niño forcing on ${ }^{10} \mathrm{Be}$-based surface denudation rates in the northwestern Peruvian Andes?, Geomorphology, 123, 257-268, 2010.

Abbühl, L. M., Norton, K. P., Jansen, J., Schlunegger, F., Aldahan, A., and Possnert, G.: Landscape transience and mechanisms of knickpoint retreat from ${ }^{10} \mathrm{Be}$ in the Western Escarpment of the Andes between Peru and northern Chile, Earth Surf. Proc. Land., 36, 1464-1473, 2011.

Agteca: Global Historical Climatology Network (GHCN-Monthly database) compilation for Peru, edited by: Cochrane, T. A., Agteca.org, available at: www.agteca.org, 2010.

Baker, P. A., Rigsby, C. A., Seltzer, G. O., Fritz, S. C., Lowenstein, T. K., Bacher, N. P., and Veliz, C.: Tropical climate changes at millennial and orbital timescales on the Bolivian Altiplano, Nature, 409, 698-701, 2001a.

Baker, P. A., Seltzer, G. O., Fritz, S. C., Dunbar, R. B., Grove, M. J., Tapia, P. M., Cross, S. L., Rowe, H. D., and Broda, J. P.: The History of South American Tropical Precipitation for the Past 25,000 Years, Science, 291, 640-643, 2001b.

Bekaddour, T., Schlunegger, F., Vogel, H., Delunel, R., Norton, K. P., Akcar, N., and Kubik, P. K.: Paleo erosion rates and climate shifts recorded by Quaternary cut-and-fill sequences in the Pisco valley, central Peru, Earth Planet. Sci. Lett., 390, 103-115, 2014.

Bilderback, E. L., Pettinga, J. R., Litchfield, N. J., Quigley, M., Marden, M., Roering, J. J., and Palmer, A. S.: Hillslope response to climate-modulated river incision in the Waipaoa catchment, East Coast North Island, New Zealand, Geol. Soc. Am. Bull., 127, 131-148, 2015.

Bloschl, G., Sivapalan, M., Wagener, T., Viglione, A., and Savenije, H.: Runoff Prediction in Ungauged Basins, Synthesis across Processes, Places and Scales Cambridge University press, 490 pp., 2013.

Bookhagen, B. and Strecker, M. R.: Orographic barriers, highresolution TRMM rainfall, and relief variations along the eastern Andes, Geophys. Res. Lett., 35, doi:10.1029/2007GL032011, 2008.

Bookhagen, B., D. Fleitmann, K. Nishiizumi, M. R. Strecker, and Thiede, R.C.: Holocene monsoonal dynamics and fluvial terrace formation in the northwest Himalaya, India, Geology, 34, 601604, 2006.

Carson, M. A. and Kirkby, M. J.: Hillslope Form and Process, Cambridge University Press, Cambridge, 1972.

Ferguson, R.: Flow resistance equations for gravel- and boulder-bed streams, Water Resour. Res., 43, W05427, doi:10.1029/2006WR005422, 2007.

Fritz, S. C., Baker, P. A., Lowenstein, T. K., Seltzer, and Rigsby, C. A.: Hydrologic variation during the last 170,000 years in the southern hemisphere tropics of South America, Quaternary Res., 61, 95-104, 2004.

Garreaud, R., Vuille, M., and Clement, A. C.: The climate of the Altiplano: observed current conditions and mechanisms of past changes, Palaeogeogr. Palaeoclimatol., 194, 5-22, 2003.

Hancock, G. S. and Anderson, R. S.: Numerical modeling of fluvial strath-terrace formation in response to oscillating climate, Geol. Soc. Am. Bull., 114, 1131-1142, 2002.

Heimsath, A. M., Dietrich, W. E., Nishiizumi, K., and Finkel, R. C.: The soil production function and landscape equilibrium, Nature, 388, 358-361, 1997.

Heimsath, A. M., Chappell, J., Dietrich, W. E., Nishiizumi, K., and Finkel, R. C.: Late Quaternary erosion in southeastern Australia: a field example using cosmogenic nuclides, Quatern. Int., 83, 169-185, 2001.

Heimsath, A. M., Furbish, D. J., and Dietrich, W. E.: The illusion of diffusion: field evidence for depth-dependent sediment transport, Geology, 33, 949-952, 2005.

Heimsath, A. M., DiBiase, R. A., and Whipple, K. X.: Soil production limits and the transition to bedrock-dominated landscapes, Nat. Geosci., 5, 210-214, 2012.

Heller, P. L. and Paola, C.: The large-scale dynamics of grain-size variation in alluvial basins 2: application to syntectonic conglomerate,: Basin Res., 4, 91-102, 1992.

Kober, F., Schlunegger, F., Zeilinger, G., and Schneider, H.: Surface uplift and climate change: the geomorphic evolution of the Western Escarpment of the Andes of northern Chile between the Miocene and present, Geol. Soc. Am., Special Paper, 398, $97-$ 120, 2006.

Leopold, L. B., Wolman, M. G., and Miller, J. P.: Fluvial processes in geomorphology, edited by: Freeman, W. H. and Company, San Francisco, 1964.

Litty, C., Duller, R. and Schlunegger, F.: Paleohydraulic reconstruction of a 40 kyr-old terrace sequence implies that water discharge was larger than today, Earth Surf. Proc. Land., in press, doi:10.1002/esp.3872, 2016.

Matmon, A., Bierman, P., and Enzel, Y.: Pattern and tempo of great escarpment erosion, Geology, 30, 1135-1138, 2002.

McPhillips, D., Bierman, P. R., and Rood, D. H.: Millennial-scale record of landslides in the Andes consistent with earthquake trigger, Nat. Geosci., 7, 925-930, 2014.

Meyer-Peter, E. and Müller, R.: Formulas for Bed-Load transport, Proceedings of the 3rd Conference, International Association of Hydraulic Research, Stockholm, Sweden, 39-64, 1948.

Norton, K. P., Molnar, P., and Schlunegger, F.: The role of climatedriven chemical weathering on soil production, Geomorphology, 204, 510-517, 2014.

Placzek, C., Quade, J., and Patchett, P. J.: Geochronology and stratigraphy of late Pleistocene lake cycles on the southern Bolivian Altiplano: Implications for causes of tropical climate change, Geol. Soc. Am. Bull., 118, 515-532, 2006.

Roering, J. J., Mackey, B. H., Handwerger, A. L., Booth, A. M., Schmidt, D. A., Bennett, G. L., and Cerovski-Darriau, C.: Beyond the angle of repose: A review and syn- thesis of landslide processes in response to rapid uplift, Eel River, Northern California, Geomorphology, 236, 109-131, 2015.

Schildgen, T. F., Hodges, K. V., Whipple, K. X., Reiners, P. W., and Pringle, M. S.: Uplift of the western margin of the Andean 
plateau revealed from canyon incision history, southern Peru, Geology, 35, 523-526, 2007.

Schlunegger, F., Zeilinger, G., Kounov, A., Kober, F., and Hüsser, B.: Scale of relief growth in the forearc of the Andes of Northern Chile (Arica latitude, $18^{\circ} \mathrm{S}$ ), Terra Nova, 18, 217-223, 2006.

Seidl, M. A., Weissel, J. K., and Pratson, L. F.: The kinematics and pattern of escarpment retreat across the rifted continental margin of SE Australia, Basin Res., 8, 301-316, 1996.

Shields, A.: Anwendung der Ahnlichkeitsmekanik und der Turbulenzforschung auf die Geschiebebewegung, Mittelung der preussischen Versuchsanstalt fur Wasserbau und Schiffbau, 26, Berlin, 1936.

Steffen, D., Schlunegger, F., and Preusser, F.: Drainage basin response to climate change in the Pisco valley, Peru, Geology, 37, 491-494, 2009.

Tucker, G. E. and Slingerland, R. L.: Erosional dynamics, flexural isostasy, and long-lived escarpments: a numerical modeling study, J. Geophys. Res.-Sol. Ea., 99, 12229-12243, 1994.

Tucker, G. E. and Slingerland, R.L.: Drainage basin responses to climate change, Water Resour. Res., 33, 2031-2047, 1997.

Turowski, J. M., Hovius, N., Wilson, A., and Horng, M-J.: Hydraulic geometry, river sediment and the definition of bedrock channels, Geomorphology, 99, 26-38, 2008.

Vanacker, V., von Blanckenburg, F., Hewawasam, T., and Kubik, P. W.: Constraining landscape development of the Sri Lankan escarpment with cosmogenic nuclides in river sediment, Earth Planet. Sci. Lett., 253, 402-414, 2007.

van der Beek, P., Summerfield, M. A., Braun, J., Brown, R. W., and Fleming, A.: Modeling postbreakup landscape development and denudational history across the southeast African (Drakensberg Escarpment) margin, J. Geophys. Res.-Sol. Ea., 107, doi:10.1029/2001JB000744, 2002. von Blanckenburg, F.: The control mechanisms of erosion and weathering at basin scale from cosmogenic nuclides in river sediment, Earth Planet. Sci. Lett., 242, 223-239, 2006.

von Blanckenburg, F., Hewawasam, T., and Kubik, P. W.: Cosmogenic nuclide evidence for low weathering and denudation in the wet, tropical highlands of Sri Lanka, J. Geophys. Res.-Ea. Surf., 109, doi:10.1029/2003JF000049, 2004.

Weissel, J. K. and Seidl, M. A.: Influence of rock strength properties on escarpment retreat across passive continental margins, Geology, 25, 631-634, 1997.

Whipple, K. X. and Tucker, G. E.: Implications of sediment-fluxdependent river incision models for landscape evolution, J. Geophys. Res., 107, 1-20, 2002.

White, A. F. and Blum A. E.: Climatic effects on chemical weathering in watersheds; application of mass balance approaches, in: Solute modelling in catchment systems, edited by: Trudgill, S. T., 101-131, 1995a.

White, A. F. and Blum, A. E.: Effects of climate on chemical weathering in watersheds, Geochim. Cosmochim. Ac., 59, 1729-1747, $1995 b$.

Willett, S. D., McCoy, S. W., Perron, J. T., Goren, L., and Chen, C.-Y.: Dynamic Reorganization of River Basins, Science, 343 , doi:10.1126/science.1248765, 2014.

Yalin, M. S.: River Mechanics, Pergamon, Tarrytown, NY, 219 pp., 1992. 